УДК 327.57:355 (477)

DOI: $10.33099 / 2707-1383-2020-35-1-34-47$

Лухтан А. І., кандидат історичних наук, Генеральний штаб ЗС України (м. Киї)

ORCID: 0000-0001-5403-137X

\title{
ПЕРЕДУМОВИ ТА ЕТАПИ СТВОРЕННЯ БАГАТОСТОРОННЬОЇ ВІЙСЬКОВОЇ ЧАСТИНИ ЛИТПОЛУКРБРИГ (1992-2015 рр.)
}

В умовах геополітичних трансформаиій у Центрально-Східній Європі залишається актуальним пошук нових механізмів зміџнення міжнародної безпеки. Для вирішення цієё проблеми одним із напрямів є пошук нових форм та способів розвитку міжнародного військового співробітництва. На основі аналізу сучасної наукової літератури та джерельної бази у статті досліджуються передумови становлення військового співробітництва між Україною, Республікою Польща та Литовською Республікою на прикладі формування багатосторонньої військової частини ЛИТПОЛУКРБРИГ. Окрему увагу автор приділяе участі підрозділів Збройних Сил Украӥни в спільних заходах зі збройними силами країн-членів НАТО для набуття взаємосумісності до виконання завдань за призначенням. Уведено до наукового обігу нові джерела.

Ключові слова: міжнародне військове співробітництво, військове співробітництво, украӥнсько-польське-литовське співробітництво.

Актуальність дослідження. Сучасна історична наука вивчає досвід розбудови співробітництва України 3 державами світу та міжнародними безпековими організаціями, зокрема з Північноатлантичним Альянсом. В умовах геополітичних трансформацій у Центрально-Східній Європі, денонсації Росією та США низки базових договорів із міжнародної безпеки, залишається актуальним пошук протидії агресивній російській політиці щодо сусідніх країн та їі намірів розширити так звану “зону власного інтересу".
Для вирішення цієї проблеми одним iз напрямів $€$ пошук нових форм та способів розвитку міжнародного військового співробітництва України (МВСп України). Одним із шляхів протидії російській гібридній експансії є набуття, під час багатостороннього співробітництва 3 державами-членами НАТО, спроможностей підрозділами (частинами) Збройних Сил України (ЗС України) у взаємосумісності під час спільних дій.

Аналіз останніх джерел. Аналіз історіографії міжнародного військового співробітництва засвідчив наявність 
наукового інтересу до цієї проблематики з боку польських та вітчизняних науковців і дослідників: О. Деркач [2], Л. Коберський [2], О.Кузьмук [4], В. Петрів [3], Р.Синовський [1] та інші.

У роботі Р. Синовського "Полукрбат" автор наводить аспекти військового співробітництва Республіки Польща (РП) та України у контексті створення спільного військового підрозділу польсько-українського батальйону (ПолУкрБат), що виконував миротворчі завдання в Югославії [1, с. 55].

Українська історіографія відмічає, що на початку 20-х років XX століття були спроби перших ідей та концепцій стосовно створення спільних українсько-польських підрозділів в умовах нинішньої боротьби за незалежність України. Так, у доповіді 1920 року шефу військової місії в Польщі генералу Зелінському, яка виявлена в архівах Директорії УНР львівським істориком Б. Гудем, хорунжий 6-го технічного куреня 6-ї стрілецької дивізії інженер О. Бойко пропонував створити “... перший українсько-польський дивізіон особистого призначення для державної користі, зробити досвід на цьому дивізіоні, себто перевести в життя назрівшу по сучасному моменту теорію спільної праці. Нехай би він дав нашому громадянству відповідний приклад для будучої суспільної праці в загальній боротьбі з ворожими сусідами... Дивізіон мусить бути безумовно мішаним: напівукраїнським-напівпольським.... Рахував би необхідним доручить формування цієї частини безумовно ідей- ним людям, а головне, тямущим... приймаючи до цього Дивізіону людей виключно ідейних... Рахував би за добре зробить цей дивізіон іменним, себто в честь двох державних Господарів: С. Петлюри та Ю. Пілсудського, цих двох найвиразніших та найпопулярніших вождів народних...” [2, с. 7].

Прикладом стратегічного погляду на протидії спільним загрозам у боротьбі Жовнірів Польщі та вояків Української Народної Республіки за незалежність, можливо зазначити укладання Ю. Пілсудським та С. Петлюрою союзу, який мав значення як у політичній, так і військовій сферах. Варто зазначити, що у своїх мемуарах В. Петрів визначає важливість для України на початку 20-х років XX ст. розвитку українсько-польського військового співробітництва [3].

У сучасній історії процес формування українсько-польського батальйону відстежено по “гарячих слідах” у спільній праці О. Деркача і Л. Коберського. Наведено грунтовно історичні факти, події та висновки стосовно плідної співпраці України та Республіки Польща у реалізації спільного проєкту “УКРПОЛБАТ” (1996-2001 рр.). Заслуговує на повагу висновок дослідників стосовно характеристики українсько-польського співробітництва того часу

“... як є не данина моди, а об’єктивна необхідність не лише для України та РП, а й інших держав...” [2, с. 95].

У контексті подальшого реформування ЗС України О. Кузьмук надав підсумок 10-річчя міжнародної миротворчої діяльності України. Він стверджував, 
що умови проведення міжнародних миротворчих операцій $\epsilon$ наближеними до умов можливого застосування 3С України, а практика міжнародної миротворчої діяльності стала головним джерелом набуття ними досвіду у мирний час i важливим критерієм забезпечення їхньої готовності до виконання завдань в особливий період [4, с. 6-9].

У публікаціях засобів масової інформації обмежено висвітлено досвід діяльності багатосторонньої військової частини України, Польщі і Литви $[5 ; 6]$.

Аналіз сучасних досліджень та публікацій засвідчив наявність обмеженої кількості наукових праць та неповного висвітлення еволюції концептуальних підходів стосовно спільної військової частини $з$ державами-членами НАТО.

3 огляду на сучасні умови та наявність воєнних загроз національній безпеці, виникає потреба у вивченні концептуальних підходів щодо формування спільної військової частини на прикладі створення литовсько-польсько-української військової частини ім. Великого Князя Острожського (ЛИТПОЛУКРБРИГ).

Формулювання мети. Автор даної статті, спираючись на досвід попередніх досліджень, ставить за мету розкрити зміст передумов формування багатосторонньої військової частини ЛИТПОЛУКРБРИГ. Також намагається визначити етапи еволюції концепції формування багатосторонньої частини.

Виклад основного матеріалу дослідження. Ухвалення 24 серпня 1991 року Верховною Радою України (ВРУ) рішення стосовно проголошення незалежності України, взяття під свою юрисдикцію всіх розташованих на теренах військових формувань збройних сил СРСР, утворення Міністерства оборони України (Міноборони) та визначення зовнішньої політики держави сформувало законодавче підгрунтя для започаткування МВСп України відповідно до норм і принципів міжнародного права [7-9].

Необхідно звернути увагу на те, що становлення МВСп України відбувалося в умовах формування відносин довіри та відкритості між збройними силами суміжних держав, трансформації безпекового середовища внаслідок розпаду СРСР, зокрема відмови України від ядерної зброї, скорочення звичайного озброєння відповідно до міжнародних зобов’ язань [10].

З 1992 року розпочалась миротворча діяльність України, де провідне місце серед центральних органів виконавчої влади займало Міноборони, а також підрозділи ЗС України, які залучалися до операції Організації Об’ єднаних Націй $(\mathrm{OOH})$ з підтримки миру. На початку 1992 року відповідно до пропозиції Секретаріату ООН, Україна започаткувала підготовку 240-го батальйону до виконання миротворчої місії у м. Сараєво (Боснія і Герцеговина). Одночасно український персонал був направлений до головного штабу Сил ООН з охорони (UNPROFOR) у м. Загреб на посади офіцерів оперативного відділу та 3 тилового забезпечення [11].

За спогадами Віктора Гвоздя, одного 
3 перших штабних офіцерів, у складі тилового відділу головного штабу військ ООН у колишній Югославії (м. Загреб, Республіка Хорватія) у 1993-1995 рр. вітчизняні миротворці гідно виконували свій обов'язок [12].

Протягом січня та лютого 1993 року український батальйон у взаємодії 3 французьким (FREBAT) та єгипетським (ЕGYBAT) миротворчими батальйонами забезпечили супроводження 226 конвоїв, загальною чисельністю понад 316 од. важкої техніки. За оцінками керівництва UNPROFOR українські військовослужбовці з гуманністю та неупередженістю ставилися до населення, що дозволяло створити відносини довіри [13, с. 46].

В цей час, починаючи з березня 1992 року, у складі UNPROFOR миротворчу функцію виконував польський батальйон (POLBAT). У зоні відповідальності POLBAT знаходилася місцевість, на якій була велика кількість мінних полів. Це вимагало залучення інженерних підрозділів для пошуку вибухонебезпечних предметів у складних умовах [14, с. 42-43].

Питання участі українських миротворців не залишалося поза увагою представників законодавчої влади України. Так, у липні 1993 року група народних депутатів ВРУ здійснила візит у Боснію і Герцеговину, Македонію, Союзну Республіку Югославію. Під час переговорів із керівництвом цих країн та за результатами зустрічі з командуванням миротворчих сил ООН у Боснії та українського батальйону в м. Сараєво, пар- ламентська делегація дійшла висновку щодо доцільності розширення участі України в операціях із підтримки миру на території колишньої Югославії та інших регіонів. У звіті була визнана важливість такої діяльності, яка сприятиме зміцненню миротворчого авторитету України як держави, що здійснює незалежну зовнішню політику, набуттю 3С України досвіду взаємодії зі збройними силами держав-членів НАТО та інших країн, надходженню валюти в бюджет України, підвищенню соціального захисту військовослужбовців, зокрема їхнього матеріального становища [15].

За підсумками візиту було сформульовано такі пропозиції для поліпшення розвитку миротворчої діяльності України: довести чисельність батальйону в м. Сараєво до 1000-1200 осіб; підтримати пропозиції Секретаріату ООН щодо розміщення українських військових підрозділів в інших регіонах світу; вдатися до нових для України форм співробітництва з ООН - здавання в оренду повітряних суден із екіпажами, цивільної і військової техніки; направлення офіцерів - військових спостерігачів ООН в усі регіони світу, а також цивільної і військової поліції, цивільних фахівців для роботи в місіях $\mathrm{OOH}$; частину валюти, що надходить в Україну за перебування військових підрозділів у складі миротворчих сил, перераховувати Міноборони. Разом з тим визначено завдання Міноборони: мати військові частини всіх родів військ у готовності до участі в миротворчих операціях в усьому світі; створити спеціальний на- 
вчальний центр для підготовки миротворчих підрозділів; створити управління для централізованого керівництва миротворчою діяльністю ЗС України; дозволити здійснювати набір військовослужбовців у миротворчі контингенти на умовах контракту до прийняття спеціального законодавства; інформувати громадян про миротворчі місії, в яких беруть участь військовослужбовці ЗС України через державні телерадіокомпанії [16].

У листопаді 1993 року відповідно до Постанови ВРУ “Про збільшення чисельності батальйону ЗС України в миротворчих силах $\mathrm{OOH}$ на території колишньої Югославії та відправлення груп військових спостерігачів" до складу СООНО на території колишньої Югославії було включено український контингент, ядром якого був 240 ОСБ. Відповідно до Резолюції Ради Безпеки ООН від 15 грудня 1995 року № 1031 були створені багатонаціональні сили 3 виконання Угоди щодо Боснії і Герцеговини 3 метою проведення операції 3 надання допомоги в реалізації домовленостей, досягнутих конфліктуючими сторонами і закріплених у Паризькій мирній угоді 1995 року.

Наприкінці грудня 1995 року було передано повноваження від СООНО до Сил із виконання Угоди. Україна була запрошена від керівництва НАТО та відповідно до рішення Уряду України направила 240 ОСБ (чисельністю 550 осіб), а також ескадрилью літаків (на комерційній основі) [16, с. 369].

У грудні 1996 року РБ ООН одно- стайно схвалила резолюцію № 1088, згідно з якою було санкціоновано розгортання багатонаціональних стабілізаційних сил (SFOR) на 18 місяців як правонаступників сил із виконання Угоди. Ще одним свідченням рішучості України зробити внесок у справу встановлення міцного і тривалого миру на Балканах стала участь у миротворчій операції ООН у Східній Славонії, до якої було залучено танкову роту і дві ескадрильї вертольотів. У подальшому, в зв'язку зі скороченням військового контингенту, танковий підрозділ змінила механізована рота, а 3 двох вертолітних ескадрилій було сформовано одну [16, c. $371 ; 4$ c. 5$]$.

Підсумовуючи, можна зазначити, що перший досвід участі в миротворчій операції ЗС України був безцінним. Підтвердженням цього $є$ оцінки, які надав у 1994 році командувач Одеського воєнного округу, зокрема він окреслив такі аспекти, що сприятимуть участі військових частин (підрозділів) у миротворчій діяльності: визначення чіткої системи підпорядкованості командування 240 ОСБ; удосконалення механізму комплектування посад за дефіцитними спеціальностями та процедури проведення ротації; делегування повноважень щодо комплектування особового складу; визначення форми контракту на проходження служби у складі контингенту $\mathrm{OOH}$; узагальнення аналізу та впровадження досвіду проходження служби у складі миротворчих сил $\mathrm{OOH}$, шляхом написання відповідного звіту про особливості служби [17]. 
Варто зазначити, що досвід спільного виконання миротворчих завдань у колишній Югославії підрозділами 3С України зі збройними силами РП, сприяв розширенню формату військового співробітництва між ними.

Так, уперіодз 23.09 до 04.10.1996 року під час навчань "Татри-96" (“Tatra-96”) на полігоні Нова Демба (Польща) відбулася перша апробація дієздатності організаційно-штатної структури та концепції дій спільного українсько-польського батальйону у виконанні миротворчих завдань. Від польської сторони брав участь 1-й танковий батальйон 14 ТБР, від української сторони - дві роти 310-го механізованого полку 24 МД зі штатним озброєнням у складі 180 осіб, з них 28 офіцерів [2, с. 10]. Протягом 1996-1998 рр. тривало активне обговорення та узгодження основних напрямів створення спільної військової частини, зокрема визначено українську та польську складові, які взяли участь у проведенні першого спільного навчання "Татри-96" (“Tatra-96") 3 миротворчої тематики, що стало підгрунтям до підготовчих заходів зі створення українсько-польського батальйону [2, с. 95].

У листопаді 1997 року під час робочого візиту в м. Варшаву міністри оборони України і РП підписали угоду між Україною та Польщею у справі створення спільної військової частини для участі в міжнародних миротворчих і гуманітарних операціях під егідою міжнародних організацій [18].

Ця угода стала правовим підгрунтям для формування спільного українськопольського батальйону.

Протягом 1997-1998 pp. 208-й українсько-польський окремий спеціальний батальйон набував спроможностей для участі в багатонаціональних операціях, зокрема під час багатонаціонального командно-штабного навчання (КШН) “Бравий орел” (вересень 1997 р., полігон Дравсько, РП); тактичного навчання в рамках КШН “Щит миру-98” (вересень 1998 р.); двох КШН з проблем оперативних процедур ООН (квітень i червень 1998 р., на базі 14 ТБР Краківського ВО, РП) [2, с.18-20].

У січні 1998 року президенти України і РП відвідали українсько-польський батальйон та ознайомилися із результатами співпраці між збройними силами двох держав, зокрема злагодженості дій, стройового вишколу та побутових умов спільного українсько-польського підрозділу. Дієвим чинником було залучення до участі у миротворчій операції штатного підрозділу. Так, у березні 1998 року штатний підрозділ 208-го українсько-польського окремого спеціального батальйону у складі 77 військовослужбовців, зокрема 6 офіцерів і трьох прапорщиків, почав виконувати миротворчі завдання у Боснії. На відміну від 60 ОСБ, зазначений підрозділ відбув зі своїм штатним складом 9 березня 1998 року та прибув у м. Мостар у зону відповідальності 240 ОСБ. Зона відповідальності була визначена у складі багатонаціональних сил із виконання мирних домовленостей щодо Боснії, досягнутих у м. Детройті (IFOR). 3 по- 
чатку 1999 року підрозділ виконував завдання командування стабілізаційних сил (CFOR) та організаційно підпорядковувався командуванню німецької бригади “Центр”, яка входила до складу французької дивізії “Саламандра". Українські миротворці контролювали зону відповідальності площею 400 км², у якій перетиналися інтереси боснійських мусульман, хорватів і сербів, перебували на ділянці стратегічно важливої дороги Мостар-Сараєво, охороняли міст через р. Неретва. Так званий Алексін міст на півдорозі від м. Мостар до м. Сараєво столиці (Боснії та Герцеговини) мав стратегічне значення, тому що з'єднував Північну та Південну Свропу. Охорона цього об'єкта була одним iз найважливіших завдань міжнародних Стабілізаційних сил i покладалася на особовий склад “Укрполбату” [2, с. 30].

Підсумовуючи, зазначимо важливість цього етапу еволюції концепції формування багатосторонньої частини для зміцнення відносин довіри між суміжними державами, де ключовою точкою дотику був досвід миротворчої діяльності стосовно досягнення миру i безпеки в Європі.

3 липня 2000 року військовослужбовці спільного українсько-польського миротворчого батальйону "УкрПолбат" розпочали виконання завдань у складі багатонаціональної бригади “Схід” сил KFOR, а саме: патрулювання; несення служби на блокпостах; несення служби на спостережних постах; супроводження конвоїв та місцевого населення; охорона шкіл та церков [2].
27 липня 2001 року під час Дня високоповажних гостей навчання “Щит миру-2001" на Яворівському полігоні за участю міністрів оборони України та РП, відбулася урочиста церемонія проводів українсько-польського батальйону до місця виконання миротворчої місії в Косово. Наступного дня відбулася церемонія проводів українсько-польського батальйону у м. Жешув (Польща) за участю керівників оборонних відомств України та РП.

Як зазначив аташе з питань оборони Посольства РП в Україні В. Ярушевський: “...військовослужбовці українсько-польського батальйону надавали допомогу населенню м. Косово, здійснюючи гуманітарні акції для мешканців населених пунктів, які входять до зони відповідальності “УкрПолбат”. Наприклад, один із таких благодійних заходів відбувся в центрі “Лахор”, де мешкали десятки родин сербських біженців із усіх куточків м. Косово. Саме для дітей 3 малозабезпечених сімей українські, польські й американські військовослужбовці зі складу багатонаціональної бригади "East" сил KFOR презентували солодкі подарунки " [19, с. 15].

Незважаючи на практичні кроки реалізації концепції створення спільної військової частини, негативно впливали на хід іiі реалізації внутрішні чинники, які не дозволяли завершити імплементацію намірів воєнно-політичного керівництва України та Польщі в міжнародно-правовому полі.

Так, через внутрішньополітичні протиріччя лише у квітні 2000 року ВРУ 
ухвалила Закон України "Про ратифікацію Угоди між Україною та РП у справі створення спільної військової частини для участі в міжнародних миротворчих і гуманітарних операціях під егідою міжнародних організацій”. Метою укладання міждержавного договору було створення спільного батальйону для участі у ММО відповідно до мандату РБ ООН та інших міжнародних організацій, відповідальних у сфері підтримання міжнародного миру та безпеки, а також у складі багатонаціональних сил, сформованих за згодою РБ ООН. У договорі було врегульовано питання підготовки, управління і забезпечення виконання завдань, а також обов'язки договірних сторін [18].

Договір мав цінність для розвитку стратегічного партнерства в цілому та українсько-польського військового співробітництва зокрема.

3 червня 2005 року було розпочато роботу щодо створення спільного литовсько-польсько-українського підрозділу.

У квітні 2008 року у м. Варшаві відбулася чергова робоча зустріч експертів Збройних Сил України, РП і Литовської Республіки. За результатами зустрічі опрацьовано проєкт Технічної угоди щодо створення спільного військового підрозділу “ЛитПолУкрбат”. Протягом 2008 року було проведено низку зустрічей експертів України, РП і Литви, за результатами яких підготовлено концепцію про створення спільного українсько-польсько-литовського миротворчого підрозділу та попередньо обговорено графік-схему термінів опра- цювання проєкту тристоронньої Угоди стосовно створення спільного батальйону (перша половина 2008 року), технічної угоди (кінець 2008 року), спільного штабу батальйону та проведення спільного навчання (червень 2009 року), злагодження підрозділів шляхом теоретичної та практичної підготовки батальйону (кінець 2009 року). Концепцією створення “ЛитПолУкрбату” передбачалося розмістити спільний штаб батальйону на території України.

У 2009 році тривала подальша робота 3 внутрішньовідомчого погодження проєкту Угоди між Кабінетом Міністрів України, Урядом Литовської Республіки та Урядом РП щодо створення спільного військового підрозділу “ЛИТПОЛУКРБАТ".

У листопаді 2009 року у Брюсселі керівництво оборонних відомств України, РП і Литви підписало Лист намірів щодо створення спільної литовськопольсько-української миротворчої бригади - “ЛИТПОЛУКРБРИГ”. Для реалізації цієї багатосторонньої ініціативи передбачалася підготовка пропозицій стосовно організаційно-штатної структури, механізму іiі фінансування, а також ротації іiі командування на всіх рівнях. Основним завданням (головною місією) була участь у миротворчих і гуманітарних операціях під егідою $\mathrm{OOH}$, HATO i EC [19, c. 15].

У січні 2010 року польська сторона денонсувала Угоду між Україною та РП у справі створення спільної військової частини для участі в міжнародних миротворчих i гуманітарних операціях 
під егідою міжнародних організацій, про що повідомила дипломатичними каналами. У травні 2011 року цей двосторонній міждержавний міжнародний договір втратив чинність.

Протягом 2010-2011 рр. тривало створення литовсько-польсько-української бригади “ЛИТПОЛУКРБРИГ”. За результатами тристоронніх переговорів досягнуто домовленостей щодо завершення роботи над Угодою про формування багатонаціонального з'єднання у 2012 році [20].

На рівні оборонних відомств було визначено: до кінця березня 2011 року опрацювати та підписати Меморандум; до кінця 2011 року - опрацювати та підписати Технічну угоду; до кінця 2012 року - створити штаб бригади та досягнути початкових оперативних спроможностей; протягом 2013 року - провести КШН бригади, з метою оцінювання іiі готовності до взяття участі в операціях відповідно до стандартів НАТО та ЄС; до кінця 2013 року - досягнути повної оперативної спроможності; протягом 2014 року - досягнути готовності брати участь в операціях і місіях.

У листопаді 2010 року міністри оборони України і РП підписали Технічну угоду між Міністерством оборони України та Міністром національної оборони Республіки Польща "Про направлення українського миротворчого персоналу для виконання завдань у складі польського військового контингенту у провінції Газні, в межах Міжнародних сил сприяння безпеці в Ісламській Республіці Афганістан", яка набула чинності
3 дня підписання [21]. Це стало правовим підгрунтям для спільної участі в операції НАТО в Ісламській Республіці Афганістан та набуття українськими військослужбовцями практичного досвіду в кризовій ситуації. Важливим аспектом інтенсифікації співробітництва 3 РП стали щорічні стажування представників МОУ та ГШ ЗС України у структурних підрозділах Міністерства національної оборони РП та ГШ Війська Польського. Протягом 2011 року стажування пройшли п'ять представників ЗС України. [22].

На розвиток концепції створення литовсько-польсько-української бригади “ЛИТПОЛУКРБРИГ” впливали зовнішні та внутрішні чинники, зокрема послаблення воєнно-політичної активності у 2010-2013 рр., що, ймовірно, пов'язано iз внутрішньополітичними змінами в Україні та поверненням іiї політики до ідеї позаблокового статусу [10].

Водночас різкі зміни у воєнно-політичній обстановці навколо України на початку 2014 року, що призвели до незаконної російської анексії АР Крим та збройній агресії з боку РФ, стали каталізатором до зміцнення заходів литовсько-польсько-українського співробітництва. Як наслідок, 19 вересня 2014 року у Варшаві міністри оборони Литовської Республіки, РП та України заснували військову частину “ЛИТПОЛУКРБРИГ”. Спільна бригада складається $з$ міжнародного штабу, трьох батальйонів та спеціальних підрозділів.

25 січня 2015 року відбулося відкриття штабу спільної військової частини 
“ЛИТПОЛУКРБРИГ” у місті Люблін, після чого відбулося набуття ним оперативної спроможності щодо планування та застосування підпорядкованих підрозділів. Повна сертифікація готовності спільної військової частини "ЛИТПОЛУКРБРИГ” за стандартами НАТО до участі в миротворчих операціях була завершена 15 лютого 2016 року [23].

Висновок. За результатом дослідження наявних джерел логічно визначити такі етапи трансформації концепції багатосторонньої військової частини:

- перший етап (1992-1997 рр.) - на фоні отримання першого миротворчого досвіду підрозділами та штабним персоналом 3С України формуються теоретичні, організаційні та правові основи концептуальних засад створення спільної миротворчої військової частини, зокрема було визначено українську та польську складові цієї частини;

- другий етап (листопад 1997-2009 pp.) - формування договірно-правового забезпечення концептуальних підходів спільного українсько-польського батальйону "УкрПолбат" дозволяє повноцінно реалізувати наміри воєнно-політичного керівництва двох держав та започаткувати практичну миротворчу діяльність. Особливістю цього етапу була наявність дисбалансу між внутрішніми та зовнішніми чинниками, що негативно впливало на формування багатосторонньої військової частини. Проте, не зважаючи на такі умови, високий рівень довіри між збройними силами дозволив підготувати спільний підрозділ до виконання складних завдань та набути практичного досвіду в досягненні миру і безпеки в Європі. Внаслідок позитивного досвіду було розпочато розробку нової концепції спільного військового підрозділу “ЛИТПОЛУКРБАТ";

- третій етап (листопад 2009-2015 р.) - розпочинається активне обговорення концептуальних засад спільного військового підрозділу "ЛИТПОЛУКРБАТ” та його трансформація у формат спільної військової частини “ЛИТПОЛУКРБРИГ”. На фоні активної роботи оборонних відомств стосовно просування формату спільної військової частини "ЛИТПОЛУКРБРИГ" та участі підрозділів збройних сил в операціях та місіях під егідою ООН, НАТО та ЄС, протягом 2012-2013 pp. на державному рівні було втрачено ініціативу щодо формування “ЛИТПОЛУКРБРИГ”. Разом із тим, поява потенційної загрози $з$ боку РФ та створення нею нової зони небезпеки у Центрально-Східній Європі прискорило практичну реалізацію проєкту “ЛИТПОЛУКРБРИГ".

Підсумовуючи, зазначимо, що провідною умовою створення військової частини “ЛИТПОЛУКРБРИГ” були спільні інтереси Литовської Республіки, Республіки Польща та України у сфері забезпечення міжнародного миру та безпеки у Європі. За цих обставин концептуальні підходи створення спільної миротворчої військової частини змі- 
нювалися в залежності від активності воєнно-політичного керівництва держав та їхньої готовності зробити внесок у забезпечення міжнародного миру i безпеки в регіоні та світі.

3 прикладної точки зору, обмін досвідом, здобуття нових теоретичних i практичних навиків за стандартами НАТО під час спільних тренувань (навчань), виконання миротворчих (спеціальних) завдань сприяло набуттю спроможностей Збройних Сил України до спільних дій.

\section{Список використаних джерел і літератури}

1. Synowski R. POLUKRBAT (Polsko-ukraiński batalion) // Polska i Ukraina w kształtowaniu bezpieczństwa europejskiego. - Przemyśl, 2007.

2. Деркач О.Т. Українсько-польський батальйон: історія і сучасність (нарис) / О. Т. Деркач, Л. В. Коберський. - Львів: Плай, 2001 - 124 с.

3. Петрів Всеволод. Військово-історичні праці. Спомини. - К.: Поліграф книга, 2002.- 640 с.

4. Кузьмук О. І. На варті миру та міжнародного правопорядку // Наука і оборона. 2002. № 2 C.3-9.

5. “УКРПОЛБАТ”: Братерство, перевірено часом // Військо України. 2007. № 9 (87), С.12-14.

6. The Grand Hetman Konstiantyn Ostrogski Lithuanian-Polish-Ukrainian Brigade LITPOLUKRBRIG [Електронний ресурc]. URL: http://www.litpolukrbig.wp.mil.pl. Назва з екрана (дата звернення: 11.09.2019).

7. Про державний суверенітет України : Декларація Верховної Ради УРСР [від 16 лип. 1990 р. ] // Відомості Верховної Ради. - 1991.- N 38, - С. 502.

8. Про проголошення незалежності України : Постанова Верховної Ради УРСР [від 24 серп. 1991р. ] // Відомості Верховної Ради .- 1991.- N 38, - С. 502.

9. Про військові формування в Україні : Постанова Верховної Ради України [від 24 серп. 1991 р. ] // Відомості Верховної Ради України . - 1991. - N 38. - С. 506.

10. Лухтан А. І. Міжнародне військове співробітництво України (1991-2013 рр.): автореф. дис. канд. іст. наук: 20.02.22; Нац. ун-т оборони України. Київ, 2019. С. 22.

11. Лист Міністерства оборони України на ім'я першого заступника міністра закордонних справ України щодо стану підготовки першого миротворчого підрозділу (240-го окремого спеціального батальйону Збройних Сил України) до участі у миротворчій операції під егідою ООН // ГДА МО України. Ф. 3657. Оп. 18640. Спр. 5. Арк. 80-82. Оригінал.

12. Екс-голова Служби зовнішньої розвідки Віктор Гвоздь: “Дуже мало успішних миротворчих місій ООН. Все одно все буде вирішуватися в зовсім інших місцях та в інших кабінетах”. [Електронний ресурc]. URL: https:/www.ukranews.com/ua/interview/1887-viktor-gvozd-duzhemalo-uspishnykh-myrotvorchykh-misiy-oon-vse-odno-vse-bude-vyrishuvatysya-v (дата звернення: 05.02.2018). 
13. Lt. Col A. Khalo UKRBAT: in real war condition // UNPROFOR Magazine, Number 2, March / April 1993 p. 46.

14. Maj. A. Rudawski POLBAT: People of Good work // UNPROFOR Magazine, Number 2, March / April 1993 p. 42-43.

15. Звіт за результатами візиту делегації України до Боснії і Герцеговини, Македонії, Союзної Республіки Югославії // ГДА МО України. Ф. 3697. Оп. 34747. Спр. 26. Арк. 75-79. Оригінал.

16. Воєнна безпека України на межі тисячоліть / Г. М. Перепелиця та ін.; Нац. інститут стратегічних досліджень. Київ: Стилос, 2002. С. 394.

17. Доповідь командувача Одеського військового округу щодо досвіду підготовки першого миротворчого підрозділу (240-го окремого спеціального батальйону Збройних Сил України) до участі у миротворчій операції під егідою ООН // ГДА МО України. Ф. 3657. Оп. 23906. Спр. 8. Арк. 74-75. Оригінал.

18. Угода між Україною та Республікою Польща у справі створення спільної військової частини для участі в міжнародних миротворчих і гуманітарних операціях під егідою міжнародних організацій від 26.11.1997: міжнародний договір (угоду ратифіковано Законом № 1634-III (163414) від 06.04.2000; втратила чинність 01.05.2011) [Електронний ресурс]. URL: http://zakon5. rada.gov.ua/laws/show/1634-14. Назва з екрана.

19. Ярушевські В. Як колишній льотчик зі стажем, можу сказати: пілотувати гелікоптери, які модернізували на ваших авіазаводах, одне задоволення // Військо України. 2010. №4 (118). С. 14 -19.

20. Біла книга-2011: оборонна політика України: щорічник. Київ, 2012.С. 83.

21. Біла книга-2012: оборонна політика України: щорічник. Київ, 2013. С. 73.

22. Біла книга-2013: оборонна політика України: щорічник. Київ, 2014. С. 74.

23. LITPOLUKRBRIG is one of the largest and most ambitions military cooperation projects. [Електронний pecypc]. URL: http://litpolukrbrig.wp.mil.pl/en/91.html. (дата звернення: 05.12.2019).

\section{References}

1. Synowski R. POLUKRBAT (Polsko-ukraiński batalion) // Polska i Ukraina w kształtowaniu bezpieczństwa europejskiego. - Przemyśl, 2007.

2. Derkach O.T. Ukrainian-polish batalion history and currently / O.T.Derkach, L.V.Koberskyi. Lviv: Plai, $2001-124$ p.

3. Petriv Vsevolod. Military-history work. Memoirs. - K.: Polihraf knyha, 2002.- 640 p.

4. Kuzmuk O.I. Na varti myru ta mizhnarodnoho pravoporiadku // Nauka i oborona. 2002. № 2 p.3-9.

5. “UKRPOLBAT”: Braterstvo, perevireno chasom // Viisko Ukrainy. 2007. № 9 (87), p. 12-14.

6. The Grand Hetman Konstiantyn Ostrogski Lithuanian-Polish-Ukrainian Brigade LITPOLUKRBRIG [Електронний ресурc]. URL: http://www.litpolukrbig.wp.mil.pl. Назва з екрана (дата звернення: 11.09.2019).

7. Pro derzhavnyi suverenitet Ukrainy : Deklaratsiia Verkhovnoi Rady URSR [vid 16 lyp. 1990 r. ] // Vidomosti Verkhovnoi Rady. - 1991.- N 38, - p. 502. 
8. Pro proholoshennia nezalezhnosti Ukrainy : Postanova Verkhovnoi Rady URSR [vid 24 serp. 1991r. ] // Vidomosti Verkhovnoi Rady .- 1991.- N 38, - p. 502.

9. Pro viiskovi formuvannia na Ukraini : Postanova Verkhovnoi Rady Ukrainy [vid 24 serp. 1991 r. ] // Vidomosti Verkhovnoi Rady Ukrainy . - 1991. - N 38. - p. 506.

10. Lukhtan A.I. International military cooperation of Ukraine (1991-2013 yy.): abstracal. of dissertation phd: 20.02.22; Nats. un-t oborony Ukrainy. Kyiv, 2019. p. 22.

11. Lyst Ministerstva oborony Ukrainy na im'ia pershoho zastupnyka ministra zakordonnykh sprav Ukrainy shchodo stanu pidhotovky pershoho myrotvorchoho pidrozdilu (240-ho okremoho spetsialnoho batalionu Zbroinykh Syl Ukrainy) do uchasti u myrotvorchii operatsii pid ehidoiu OON // HDA MO Ukrainy. F. 3657. Op. 18640. Spr. 5. Ark. 80-82. Oryhinal.

12. Eks-holova Sluzhby zovnishnoi rozvidky Viktor Hvozd: Duzhe malo uspishnykh myrotvorchykh misii OON. Vse odno vse bude vyrishuvatysia v zovsim inshykh mistsiakh ta v inshykh kabinetakh [Elektronnyi resurs]. URL: https://www.ukranews.com/ua/interview/1887-viktor-gvozd-duzhe-malo-uspishnykh-myrotvorchykh-misiy-oon-vse-odno-vse-bude-vyrishuvatysya-v (data zvernennia: 05.02.2018).

13. Lt. Col A. Khalo UKRBAT: in real war condition // UNPROFOR Magazine, Number 2, March / April 1993 p. 46.

14. Maj. A. Rudawski POLBAT: People of Good work // UNPROFOR Magazine, Number 2, March / April 1993 p. 42-43.

15. Zvit za rezultatamy vizytu delehatsii Ukrainy do Bosnii i Hertsehovyny, Makedonii, Soiuznoi Respubliky Yuhoslavii // HDA MO Ukrainy. F. 3697. Op. 34747. Spr. 26. Ark. 75-79. Oryhinal.

16. Voienna bezpeka Ukrainy na mezhi tysiacholit / H.M. Perepelytsia ta in.; Nats. instytut stratehichnykh doslidzhen. Kyiv: Stylos, 2002. p. 394.

17. Dopovid komanduvacha Odeskoho viiskovoho okruhu shchodo dosvidu pidhotovky pershoho myrotvorchoho pidrozdilu (240-ho okremoho spetsialnoho batalionu Zbroinykh Syl Ukrainy) do uchasti u myrotvorchii operatsii pid ehidoiu OON // HDA MO Ukrainy. F. 3657. Op. 23906. Spr. 8. Ark. 74-75. Oryhinal.

18. Uhoda mizh Ukrainoiu ta Respublikoiu Polshcha u spravi stvorennia spilnoi viiskovoi chastyny dlia uchasti v mizhnarodnykh myrotvorchykh i humanitarnykh operatsiiakh pid ehidoiu mizhnarodnykh orhanizatsii vid 26.11.1997: mizhnarodnyi dohovir (uhodu ratyfikovano Zakonom № 1634-III (1634-14) vid 06.04.2000; vtratyla chynnist 01.05.2011) [Elektronnyi resurs]. URL: http://zakon5. rada.gov.ua/laws/show/1634-14. Nazva z ekrana.

19. Yarushevski V. Yak kolyshnii lotchyk zi stazhem, mozhu skazaty: pilotuvaty helikoptery, yaki modernizuvaly na vashykh aviazavodakh, odne zadovolennia // Viisko Ukrainy. 2010. №4 (118). S. 14-19.

20. White book-2011: defense policies of Ukraine: yearbook. Kiyv, 2012.p. 83.

21. White book-2012: defense policies of Ukraine: yearbook. Kiyv, 2013. C. 73.

22. White book-2013: defense policies of Ukraine: yearbook. Kiyv, 2014. C. 74.

23. LITPOLUKRBRIG is one of the largest and most ambitions military cooperation projects. [Електронний ресурc]. URL: http://litpolukrbrig.wp.mil.pl/en/91.html. (дата звернення: 05.12.2019). 
Lukhtan A. I., Doctor of philosophy in the sphere of historical Sciences, the General Staff of the Armed Forces of Ukraine (Kyiv)

\section{PRECONDITION AND EVOLUTION OF CREATING THE MULTILATERAL MILITARY UNIT NUMBER “LITPOLUKRBRIG” (1992-2015)}

In the context of geopolitical transformations in Central and Eastern Europe, the search for new mechanisms to strengthen international security remains relevant. To address this issue, one of the directions is to seek new forms and ways of developing international military cooperation. Based on the analysis of modern scientific literature and source base, the author has studied the prerequisites for the establishment of military cooperation between Ukraine, Poland and the Republic of Lithuania by the example of the formation of a multilateral military unit LITPOLUKRBRIG. The author pays special attention to the participation of the unit Armed Forces of Ukraine in joint activities with the armed forces of NATO member states to acquire interoperability to perform task for their intended purpose.

It has been proved that the leading condition for the creation of the LITPOLUKRBRIG military unit was common interest of the Republic of Lithuania, the Republic of Poland and Ukraine in the field of ensuring international peace and security in Europe. At the same time, the conceptual approaches to establishing a joint peacekeeping military unit have changed depending on the activity of the military and political leadership of the states and their readiness to participate in ensuring international peace and security in the region and the world.

The conducted study allows asserting that exchange of experience, obtaining of new theoretical and practical skills according to NATO standards during joint trainings (exercises), performance of peacekeeping (special) tasks promoted acquisition of abilities of the Armed Forces of Ukraine to joint action.

At the same time, the authors periodization of the evolution of the conceptual fundamentals for the formation of a multilateral military unit LITPOLUKRBRIG was proposed and the prerequisites for each stage were described: the first stage (1992-1997); the second stage (November 1997-2009); the third stage (November 2009-2015). New sources have been introduced into scientific circulation.

Keyword: international military cooperation, military cooperation, Ukraine-PolishLithuanian cooperation. 